\title{
Forum
}

\begin{abstract}
Forum Policy: Members of the Association are invited to submit letters commenting on any article published in $P M L A$, or on matters of scholarly and critical interest to readers generally. Such letters, if accepted by the Editor, will be sent to the author of the work commented on, who will be invited to reply. The usual rules regarding courtesy and avoidance of personalities will be enforced, and the Editor reserves complete discretion in deciding whether or not to publish any letter. Letters should not exceed 1,000 words of text. Footnotes are discouraged and should be included only when absolutely necessary.
\end{abstract}

\section{Stoicism and Epicureanism in England, 1530-1700}

\section{To the Editor:}

In a recent $P M L A$ article ("Patterns of Stoicism in Thought and Prose Styles, 1530-1700," 85, 1970, 1023-34) Earl Miner rejected the accepted view that English Stoicism reached a height of popularity and influence during the age of Shakespeare and set forth the novel hypothesis that Stoicism exerted its chief influence between 1630 and 1700 , especially during the Restoration. I have pointed out that Miner's gathering and analysis of bibliographical evidence were too faulty to support his attempt to rewrite accepted intellectual and literary history ("A Misuse of Statistics in Studying Intellectual History," PMLA, 86, 1971, 1028-29). Nonetheless, in a recent Forum note Miner claims to have found new evidence to support his view and asserts that now I "must assent to . . the "formal' validation of [his] earlier contention and statistics" ("Stoicism and Prose Styles to 1700," $P M L A, 87,1972,1127)$. Far from assenting, however, I find Miner's note to be invalid because of statistical errors that are as pervasive and fundamental as those in his PMLA article.

Miner's new "evidence" consists of 19 dated and 3 undated editions of classic authors published between 1530 and 1700 , and sold in 1832 as part of a family library "Originally formed by THE POET WALLER." Besides being trivial, this evidence is misstated, because the Waller catalog lists 27 (not 22) editions of the classic authors that Miner tabulated in his article; Miner has counted a nonexistent 1568 "edition" of Livy and has not counted editions of Tacitus (in lots 360 and 452), Seneca (181), Horace (339), Lipsius (493), and Boethius (513). ${ }^{2}$ His finding that there are only four books of Stoic interest before 1700 in the catalog must be rejected, because he has omitted five editions of Tacitus, Seneca, Lipsius, and Boethius, and he has shifted ground by no longer listing Cicero's De Officiis (which is included in 6 catalog entries) as a Stoic work. A correct count based on Miner's original tabulation shows fifteen Stoic editions in the catalog, not four. Therefore, Miner's generalizations about the chronology of English Stoicism from a mere four editions must be rejected. In any case, a library "originally formed" by a poet who lived from 1606 to 1687 could not reflect current book buying or reading during most of the age of Shakespeare.

The auction catalog that Miner cites is a poor substitute for the lost "Catalogue of the Library of Edmund Waller, the Poet, in the Autograph of his Son, 2 vols. folio" (Sales Catalogues, I, 3). It is incomplete, since it lists fewer than half of the "nearly eight thousand volumes" in the Waller family library. Furthermore, of the 3,600 listed volumes, only 2,300 are identified by author or title, and of these fewer than 1,300 are dated, many of them after the poet's death. This catalog, which specifically identifies fewer than a sixth of the 8,000 volumes, was prepared to sell books, not to support a hypothesis of a modern commentator.

Waller was, however, a representative man of letters of immense contemporary reputation, and the great length of his career suggests that his life, library, and work might reflect a major change in philosophic interests from the age of Shakespeare to the Restoration. According to Miner's hypothesis, Waller ought to have moved strongly in the direction of Stoicism. In fact, however, both his contemporaries and modern commentators have found Waller to be the "most truly Epicurean of all the English poets of his age." Waller's library apparently contained a substantial number of works of Epicurean interest, both classic and modern. Furthermore, whereas Waller's Stoic books appear to have been old standard texts acquired in the process of assembling a large library, his Epicurean books appear to have been mostly new and current, including works of Hobbes, Cowley, Evelyn, Charleton, and Stanley, as well as the celebrated books by Gassendi which revived interest in Epicurus in the seventeenth century. Waller also wrote commendatory verses for the first two published English translations of Lucretius. The pattern of mostly early Stoic and mostly later Epicurean publications in the 
Waller library roughly parallels their vogue in England. Between 1478 and 1623, scores of recognized Stoic and Neo-stoic books were printed for the first time in England, but few new texts of either kind appeared after 1623. In sharp contrast to this, no classic text of Epicurean philosophy was published in England until 1656. Such learned and venturesome Elizabethans as Bacon, Burton, and Milton read Lucretius in Latin editions from the Continent, but the vernacular collections of sayings of the philosophers that were popular throughout the age of Shakespeare pointedly omitted Epicurus and Lucretius, while quoting and praising the Stoics. Nicholas Hill's pioneering Philosophia Epicurea, Democritiana, Theophrastica (1601 and 1619), which Jonson ridiculed, was published only on the Continent. After 1650, however, books of Epicurean interest were published in England with great frequency. This clear-cut pattern of publication (and nonpublication) confirms the recognized fact that the liveliest English interest in Stoicism came during the age of Shakespeare, whereas the rival interest in Epicureanism reached its height during a half century or so after 1650 . The three Restoration men of letters that Miner has mentionedHobbes, Waller, and Dryden-have all been classified as Epicureans. Many Stoic and Neostoic texts were not reprinted during the Restoration or else appeared in versions so cut and altered that some of them bordered on travesty.

A major reason why Miner's statistics and generalizations cannot be accepted is that he has taken no account of most of the Neostoic books, nearly all of which first appeared between 1566 and 1623. These books show that English readers of the age of Shakespeare demanded dozens of new books of a Stoic cast to interpret, correct, or supplement the extensive classic texts. The creation of such books shows that until 1623 Neostoicism was a vital and growing philosophy, whereas the virtual absence of new books of this kind between 1630 and 1700 indicates that after 1630 Stoicism, though still of interest to some conservatives and antiquaries, no longer concerned leading men of letters as vitally as it had in the age of Shakespeare.

\section{JoHN Freehafer}

Temple University

\section{Notes}

1 See Sales Catalogues of Libraries of Eminent Persons, ed. A. N. L. Munby (London: Mansell, 1971), I, 3-44.

${ }^{2}$ For further information on Waller's library, see Catalogue of a Portion of the Library of Major-General $W . N$. Waller, as sold by Sotheby, Wilkinson, and Hodge, London, 12 Dec. 1900. Miner errs in stating that Debates at Cicero's Tusculum and the 1659 edition of Epictetus were "printed abroad" and "purchased from the continent"; both were London publications (Wing C4307 and E3145).

${ }^{3}$ Thomas F. Mayo, Epicurus in England, 1650-1725 (Dallas: Southwest Press, 1934), pp. 175-76.

\section{Mr. Miner replies:}

John Freehafer has kindly introduced new evidence about writers who responded to Roman Stoicism, and I think that any person disinterestedly concerned in these matters must welcome that information. It is of no small interest to me that he now accepts "statistical" matters as something other than cold, antihumanistic forms of evidence. If imitation, with whatever zeal to correct, is some form of flattery, I shall say once again that $I$ do hope that we may gain from Freehafer a full-scale strategic study of the advances and retreats of forms of Neostoicism in England rather than these skirmishes, which probably interest him and me more than they do most readers.

Freehafer has still to refute the classicist who held Seneca's style Asian; he has still to refute the role of Cicero as principal purveyor of Stoicism to the Renaissance. For that matter, he has still to show his awareness of the numerous forms of classical and European Stoicism.

I must take some responsibility for this, for not stressing sufficiently that there is no one Stoicism in classical times nor in modern. To students of ancient philosophy, Zeno is far more important than Seneca, as being more original and less "soft" (Seneca was very rich, and many of his ideas are not that different from "hard" Epicureanism). The first publication in English to get such matters remotely correct, it is widely agreed, was the History of Philosophy by the poet Thomas Stanley (pub. 1655-87).

Ian Donaldson has recently published an essay on Addison's Cato that begins:

Nearly forty years ago, the late R. S. Crane showed how the early growth of the eighteenth-century cult of Sensibility was stimulated by a feeling of hostility-particularly on the part of the Latitudinarian divines-towards a contemporary revival of interest in the teachings of the Stoics. ${ }^{1}$

As the reference to the "Latitudinarian divines" and further references to works published between 1641 and 1700 show, the "eighteenth century" in this loose parlance refers to a Restoration revival of Stoicism. That phenomenon does not mean that earlier revivals had not occurred, but it is a phenomenon that Freehafer does not understand.

His claims cover "Such learned and adventuresome Elizabethans as Bacon, Burton, and Milton." I would not quarrel with their learning, their sense of adventure, or their interest in Roman Stoicism. But apart from Bacon's 1597 version of his essays, their major works were published after the demise of Elizabeth; 